\title{
A MACRO-COMPARATIVE ASSESSMENT OF WELFARE STATE CONVERGENCE IN THE EUROPEAN UNION
}

\author{
OROSZ Ágnes ${ }^{1}$ and SZIJÁRTÓ Norbert ${ }^{2}$ \\ Institute of World Economics, Centre for Economic and Regional Studies and National University of Public Service \\ Budapest, Hungary, orosz.agnes@krtk.hu \\ Institute of World Economics, Centre for Economic and Regional Studies and National University of Public Service \\ Budapest, Hungary, norbert.szijarto@krtk.hu
}

\begin{abstract}
In this paper, we provide a macro-comparative assessment of welfare state convergence. Using the welfare state regime approach, the paper analyses the development of main welfare state indicators within in the enlarged European Union. In this study we capitalize on descriptive statistics and a single convergence analysis based on standard deviation in order to capture alterations in national welfare models of 26 European countries and among acknowledged welfare regimes. Our fundamental aim is to seize on long-term processes (convergence, divergence, or persistence), so we cover almost a two-decade period starting at 2000. Our results, in general, suggest that convergence among welfare states (different indicator of social spending) of European countries is particularly weak, however convergence inside welfare regimes is significantly stronger apart from the Anglo-Saxon group. The pre-crisis period was characterized by a stronger convergence among European countries as a consequence of economic prosperity and intense EU intervention.
\end{abstract}

KEY WORDS: welfare state, welfare state regime, convergence

\section{INTRODUCTION}

European countries have different legacies regarding their welfare state models. Several factors such as economic and political ideology, social order, and historical past influence and determine the operation of different welfare state regimes. The last phase of the Great Moderation, a tranquil period before the global financial crisis, brought salient economic and social development for the European countries. The global financial crisis of 2008/2009 embarked a turbulent period and various shocks hit the countries of the European continent. The global financial crisis had a substantial negative impact on European countries with economic recession, low economic activity, accelerating unemployment and fiscal and financial tensions. The global financial crisis was followed by the euro crisis intensifying the adverse effects of economic globalization in European Union member states, and other shocks such as the Brexit and the migration crisis generated additional problems and concerns. Summarizing, since the eruption of the global financial crisis, welfare states of European countries have been substantially challenged by series of events and processes.

The aim of this study is to examine simultaneously the convergence of welfare states and national social policies and detect the impacts of EU strategies, programs, initiatives, and institutions on national welfare models. The rest of the paper is organised as follows: Section 2 reviews the literature on the theoretical framework of welfare regimes and discusses EU social policy strategies and initiatives with a particular emphasis on the OMC in a nutshell. Section 3 addresses the main methodological issues and highlights the applied methodology and empirical strategy. Section 4 displays and discusses the obtained results. And finally, the Section 5 provides the conclusions.

\section{THEORETICAL FRAMEWORK OF WELFARE REGIMES AND CONVERGENCE}

Particular values together with particular programmes and policies constitute the welfare regimes [1]. Applying a welfare regime approach tends to elicit regime-differences by using ideal-typical models [2]. Typologies are widely used in social sciences to analyse complex phenomena [3], they are method of comparative welfare state research in order to summarize the commonalities and differences among cases. Within this diversity of welfare states there are only a few clear clusters, which are broadly distinctive types and they can be understood as welfare regimes. The different welfare regimes form different "worlds of welfare capitalism" described by Esping-Andersen [4], suggesting that welfare states with diverse socio-economic circumstances can be classified within three categories (liberal, conservative and social democratic). The three different types defined by Esping-Andersen have been widely cited, criticized and developed by other scholars.

There are different understandings of how welfare states can change. The first wave of literature explains that welfare states develop path-dependently, and that they are characterized by a great immobility [5], predicting that changes are gradual. Secondly, the convergence thesis argues that welfare states gradually tend to converge upon each other [6]. Policy harmonization within the European Union is one driving force of convergence; it is assumed that institutional differences between countries will disappear as countries move in the direction of one social Europe [7]. Testing the convergence thesis, convergence is mostly a result of convergence between countries within welfare regimes, countries are converging towards the middle [8].

The European Union adopted an appealing approach, the "Open Method of Coordination" (OMC) as a new form of EU governance in order to achieve convergence in the field of social inclusion. OMC was defined as not legally binding instruments 
of the Lisbon strategy (2000), they can be regarded as soft law [9]. OMC facilitates policy learning and can be understood as a tool of building the "European Social Model" [10]. While the Lisbon Agenda had produced mixed results, Europe 2020, as the successor of the Lisbon Strategy was aimed at creating conditions to deliver a higher level of well-being for European citizens by 2030 and beyond. It is a possible threat to Europe 2020's social dimension that it will lose out in the competition for political time and attention. The OMC and any social policy coordination have been implemented in the areas where the EU has no formal competence and are regulated under the subsidiarity principle.

Using welfare state regime approach stability is a key issue. According to Esping-Andersen, regimes are the result of the influence of dominant political movements, suggesting stability over time [4]. ${ }^{1}$ Analysing welfare states, several typologies can be used. Despite all the criticism, welfare state analyses have been strongly influenced by Esping-Andersen's (1990) welfare state regime typology. Throughout the analysis we use the welfare state regime-approach in order to illustrate the developments of welfare policies. We apply the labels used by Ferrera (1996) [11] modified by Kuitto et al. (2012) [12]. The use of this classification, however, does not imply any prejudgment whether these countries do indeed form such distinct welfare clusters with regard to our welfare policy indicators, or whether the CEE countries actually form a regime of their own. We leave this question of identifying patterns or clusters of welfare policies to a later research where we recalibrate existing clusters. The regime approach in the way it is used for this chapter is simply a means to an end - to summarize and illustrate welfare policies and alterations in domestic welfare policy regimes measured by commonly employed main welfare indicators (aggregates).

Table 1. Country grouping applied in the empirical analysis.

\begin{tabular}{|c|c|}
\hline Label & Countries \\
\hline Anglo-Saxon & Ireland, United Kingdom \\
\hline Bismarckian & $\begin{array}{c}\text { Austria, Belgium, France, Germany, the } \\
\text { Netherlands, Switzerland }\end{array}$ \\
\hline Scandinavian & Denmark, Finland, Norway, Sweden \\
\hline Southern European & Greece, Italy, Portugal, Spain \\
\hline $\begin{array}{c}\text { Central and Eastern } \\
\text { European }\end{array}$ & $\begin{array}{c}\text { Bulgaria, Czech Republic, Estonia, } \\
\text { Hungary, Latvia, Lithuania, Poland, } \\
\text { Romania, Slovakia, Slovenia }\end{array}$ \\
\hline
\end{tabular}

\section{METHODOLOGY AND EMPIRICAL STRATEGY}

In this study we capitalize on descriptive statistics and a single convergence analysis based on standard deviation in order to capture alterations in national welfare models of 26 European countries and among acknowledged welfare regimes. Applied descriptive statistics consist of three elements; we calculate simple average, range, and standard deviation. Several statistical offices (including the Eurostat) and international institutions (for example the OECD) offer wide range of datasets (variables and aggregates) regarding welfare states regimes, social policy, and social protection. Basically, we rely on the dataset provided by the Eurostat, thus, we can obtain reliable and comparable data on non-OECD European countries.

\footnotetext{
1 Stability of political movements and parties and their efficient operation is decisively influenced by the internal organizational structure of the parties and the degree of their centralization or decentralization [13]. The degree of centralization-decentralization and the stability of political movements can be
}

Unique characteristics of welfare state models (and social policy goals) can be adequately described by expenditure side of national budgets, since, social expenditure as a whole and expenditure on sickness and health care, old age (pensions), family and childcare allowances and unemployment benefits. Eurostat offset two separate datasets to investigate variables and aggregate of national social expenditures. On the one hand, there is the dataset of 'Classification of the functions of government' (COFOG), which describes the broad and detailed objectives of a government. And on the other hand, there is the 'European System of integrated Social Protection Statistics' (ESSPROS), which is a common framework that enables comparing national data on social protection among European countries. In this study we rely on the ESSPROS dataset.

Our fundamental aim is to seize on long-term processes (convergence, divergence, or persistence), so we cover almost a two-decade period starting at 2000. The global financial crisis represents a crucial fracture in this time horizon; thus, we consider a pre-crisis period between 2000 and 2008 and a longterm period between 2000 and 2017. Our initial assumption is that during the first period we can detect convergence among welfare regimes and as well the 26 European countries as a consequence of higher economic prosperity and economic, social and political tranquilness. Furthermore, challenges of the last decade - economic crises, harmful impacts of globalization, new social risks, growing economic uncertainty and inequality, the Brexit and the migration crisis - probably compelled different (and divergent) responses from European countries. Therefore, national welfare state models might have changed in contrasting directions. As follows, our preliminary assumption is that crises and challenges have annulled the successes and convergence of the pre-crisis period.

In this study we examine seven different indicators in relation to national welfare models and each indicator describes crucial parts of the expenditure side of the budget. The empirical analysis, depicted by similar tables and figures, starts with general government expenditure compared to the GDP. The rationale behind the application of this indicator is that to detect alterations in welfare state models. In general, countries of the Anglo-Saxon model maintain smaller states in terms of budgetary expenditure and revenues compared to GPD, while Nordic welfare states (the Scandinavian model) historically maintain larger states bases on budgetary functions. For social expenditures, we also calculate GDP proportional values. It is worth highlighting that we do not rely on absolute values because these values are determined by several untreated factors such as the stage of economic development (difference between highly developed countries and middle-income countries) and difference in entitlement procedures. And finally, for a deeper assessment of social spending, we utilize four indicators (proportional to GDP) related to various social functions: sickness and health care expenditures, old age expenditures (pensions), family and children allowances, and unemployment benefits.

\section{DETAILED ANALYSIS AND RESULTS}

It is a common knowledge that Scandinavian countries employ a larger state in terms of expenditures and revenues compared to GDP, while Anglo-Saxon countries operate a smaller state. In 2000, the average expenditure compared to GDP was 49.08 in

measured by several methodologies, one example of which can be found in the study of Kertész (2013) [14]. 
the Scandinavian countries, while countries of the Anglo-Saxon model had a significantly smaller average expenditure compared to GDP with a value of 33.1. Countries of the Bismarckian model occupied the second place according to the indicator, while Southern European countries and Central and Eastern European countries were very close to each other by having almost the same value. Surprisingly, the pre-crisis period can not be characterized by convergence among European countries' budgetary developments. On the one hand, Bismarckian, Scandinavian and Central Eastern European countries started easing public expenditures, while in the case of Anglo-Saxon and Southern European countries we can detect an opposite process with ascending expenditures. The global financial crisis represented a sudden surge in public expenditures, this can be explained by growing social expenditures driven by the rapidly climbing number of unemployed. Since the global financial crisis, in all five country groupings, we have been witnessing a slow moderation of public spending.

Convergence can be observed by the changes in standard deviations. In the case of Scandinavian, Southern European, and Central and Eastern European welfare regimes standard deviation have decreased between 2000 and 2019. So, countries within the groups have been becoming increasingly similar. Standard deviation in the Bismarckian group have increased during the same period. The explanation for this is that in Belgium and France public expenditure compared to GDP have not normalized and moderated after the global financial crisis as happened to other countries in the group. Due to structural features (awanting structural reforms), the once-extended social expenditures have embedded into the welfare policy model of Belgium and France, and the two countries were unable to carry out comprehensive structural reforms and to reach a favourable development trajectory to cut down social expenditures. In the case of Anglo-Saxon countries, it is worth noting that the group only consists of two countries: Ireland and the United Kingdom. The two countries shared a similar path during the pre-crisis period, however, in the post-crisis era, Ireland substantially dismantled government expenditures compared to GDP. For a detailed picture see Figure 1. (constant dataset for the whole period).

In general, social spending account for half of total government expenditure in European countries. Not surprisingly, the Scandinavian model is the most generous with its citizens, in 2017 the average total social expenditure reached 29.25 in percent of GDP. This was followed by the countries of the Bismarckian model where the average social spending was 28.28 in percent of GDP. Southern European, Anglo-Saxon and Central and Eastern European countries spent significantly less than the two other country groupings, 24.88, 20.25 and 17.11 compared to GDP, respectively. Trends during the pre-crisis and post-crisis periods depict high similarity. During the last decade of Great Moderation, European countries enjoyed economic prosperity and modest catch-up process, thus social expenditures started decreasing. On the one hand, this can be tracked back to a rise in material well-being and due to the strengthening marketization (markets organize and manage tasks instead the state) the states were downsizing certain activities and services, that is the states withdrew from the market. And on the other hand, economic prosperity (economic growth) also means a statistical effect, namely faster GDP growth than growth of social expenditures. This period terminated by the global financial crisis after which social expenditures rapidly climbed up. Since crisis period, we have been witnessing declining social spending in European countries apart from the Bismarckian welfare regime where states have been unable to reduce social expenditures back to the level of the 2000s. It is worth mentioning, that the two Anglo-Saxon countries have been again following a divergent path, since Ireland have drastically axed social expenditures since the global financial crisis.
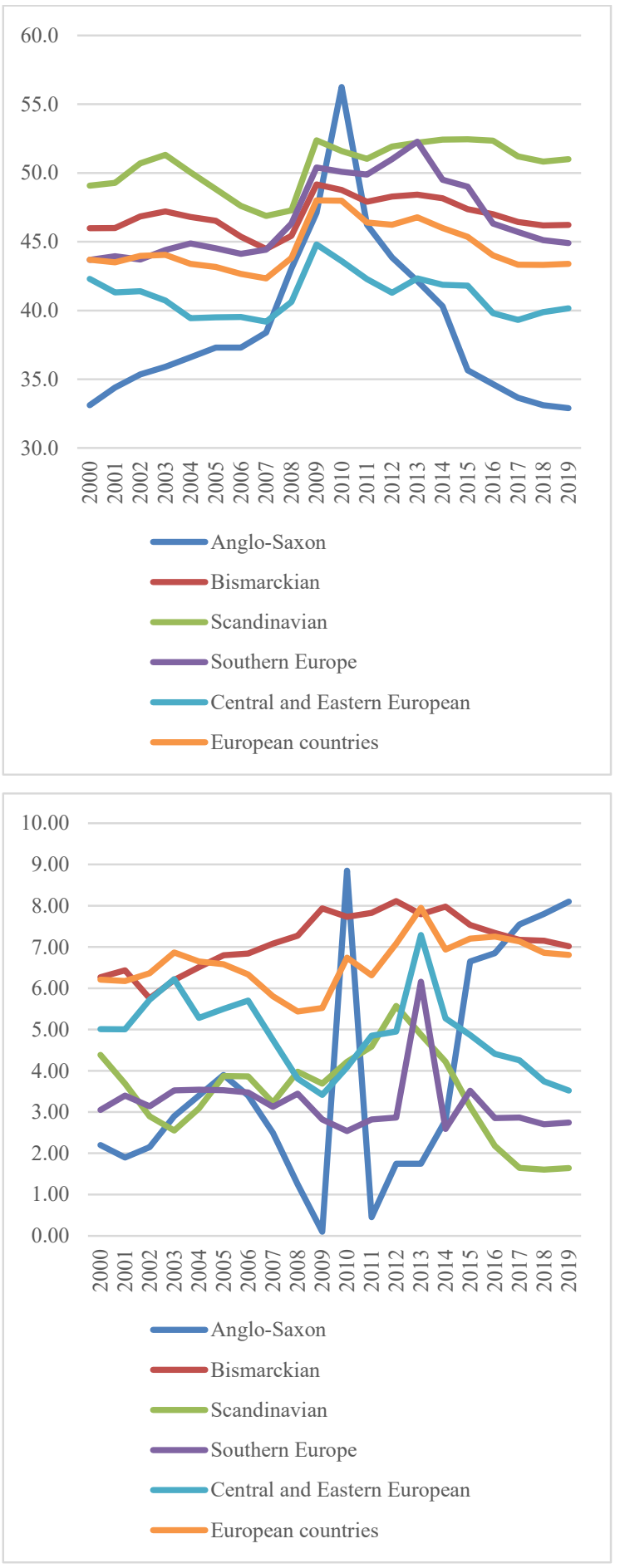

Figure 1. Two decades of government expenditure by country grouping (top: averages in \% of GPD, bottom: standard deviations).

Source: Own compilation, data extracted from the Eurostat database

Between 2000 and 2017, standard deviations have decreased in four welfare regimes: Bismarckian, Scandinavian, Southern European, and Central and Eastern European models. 
Decreasing standard deviation means that counties inside specific groups have been becoming more and more homogenous. However, it is surprising that at European level among the 26 countries there is no convergence, moreover, standard deviation has even increased during this two-decade period. The explanation for this lies in the Anglo-Saxon group; substantially divergent trends of Ireland and the United Kingdom represent a huge bias inside the Anglo-Saxon group as well at European level. Figure 2. (constant dataset for the whole period) depicts a more detailed picture regarding social expenditures by country groupings.

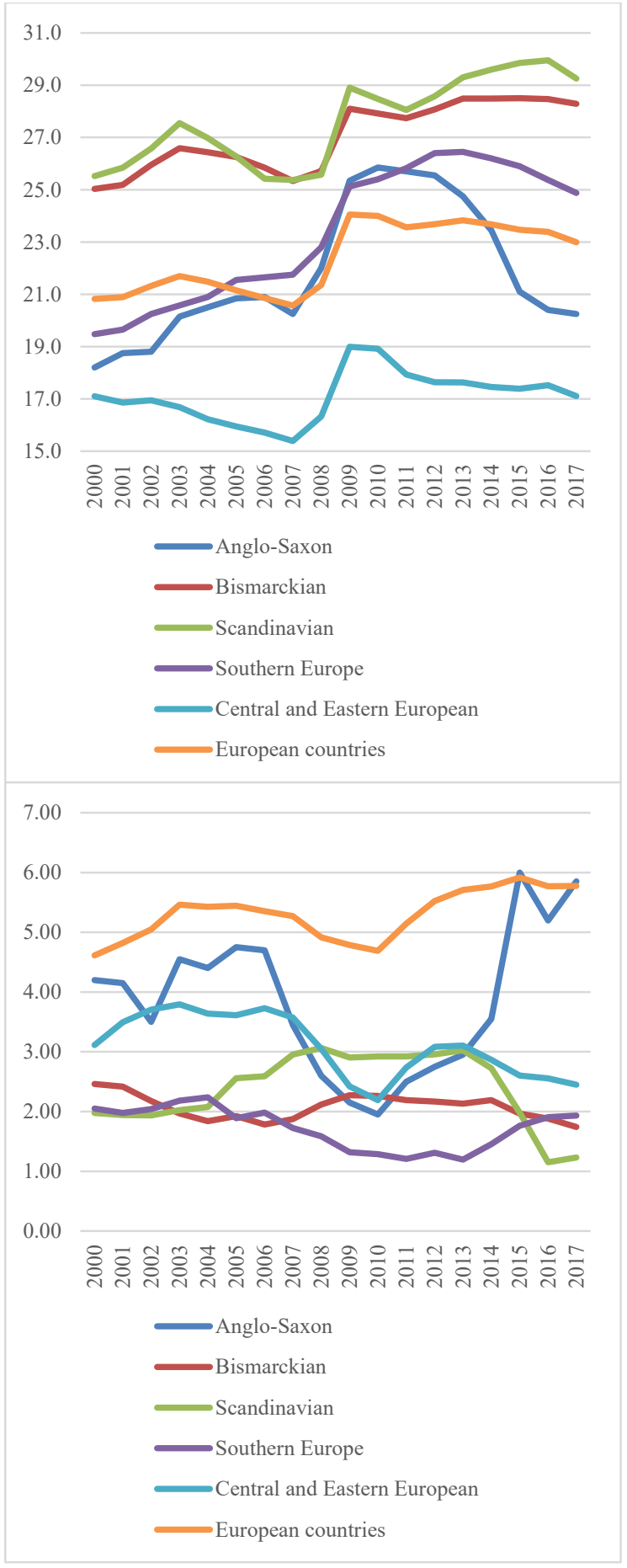

Figure 2. Two decades of social expenditures (social protection benefits) by county grouping (top: averages in $\%$ of GPD, bottom: standard deviations).
Source: Own compilation, data extracted from the Eurostat database

As we previously mentioned, economic prosperity of the precrisis period significantly decreased social spending of European countries. It is worth highlighting that in parallel, the EU launched several strategies and initiatives to boost convergence of welfare states and social policy approaches. Nevertheless, the EU's heavy interventions were not able to generate strong convergence among European welfare states and national social policies, whereas the expected impacts were annulled by the global financial crisis such as in the case of Lisbon Strategy and OMC. The prolonged recession (euro crisis), economic and social tensions in the real economy and the EU bodies newly introduced strict regulatory framework made convergence impossible for years.

Sickness and health care expenditures have generally risen in European countries during the last two decades. The increase in health care related expenditures can be explained by the rise in chronic diseases and the phenomenon of ageing. In addition, it is worth acknowledging that several European countries apply a dual structure in which public and private health care systems are coexistent. It is a striking feature that in 2017, the Bismarckian countries spent more on health care related expenditures than the Scandinavian countries with universal health care systems. In the case of the former, average health care expenditures in percent of GDP reached 8.57, while in the case of the latter it was 7.25 in percent of GDP. The third place was occupied by the average Anglo-Saxon spending followed by the Southern European and Central and Eastern European countries. The global financial again represented a striking cleavage in the trends of health care related spending (see Table 4.). Scandinavian, Southern European, and Central and Eastern European countries experienced a slight increase in health care spending, while Anglo-Saxon and Bismacrkian countries suffered from a more solid rise in that. A few years later the global financial crisis and the euro crisis, health care spending normalized at a higher level compared to the period of the $2000 \mathrm{~s}$ in all country welfare regimes. Changes in standard deviations do not demonstrate clear convergence neither inside the country groupings, nor at European level.

Demographic ageing represents a major challenge for European countries. Thus, it is not surprising that pension related spending has been constantly rising in most European countries. If we take a short look at the date related to the full sample (26 European countries), we can identify an average increase of 1.63 in percent of GDP. The situation is more drastic in Scandinavian and Southern European welfare regimes where the average old agerelated expenditures have risen by 3.55 and 2.95 in percent of GDP, respectively. Bismarckian countries have registered an above average growth in pension expenditures by 1.93 in percent of GDP. At the same time, Anglo-Saxon countries and Central and Eastern European have patrolled another trajectory. On the one hand, average spending on old age-related issues were 7.9 and 7.53 in percent of GDP, respectively, and on the other hand, these countries have not been suffered from a robustious increase in pension expenditures in terms of GDP. Our assumption is that in these countries the pay-as-you-go pension funds have been supplemented by strong private pension funds, thus, public spending (social spending) is not so much burdened by the process of demographic ageing.

Scandinavian, Southern European, and Central and Eastern European welfare regimes have been developing into more similar, however this homogeneity applies for within-group countries and not for the whole sample. In the case of Anglo- 
Saxon and Bismarckian regimes we can find divergence (rising standard deviation) among countries instead of convergence. Figure 3. provides a detailed picture on the trends regarding old age-related spending. As can be seen, enormous differences between the two Anglo-Saxon countries has a distorting impact on the standard deviation of the full sample (all 26 European countries).

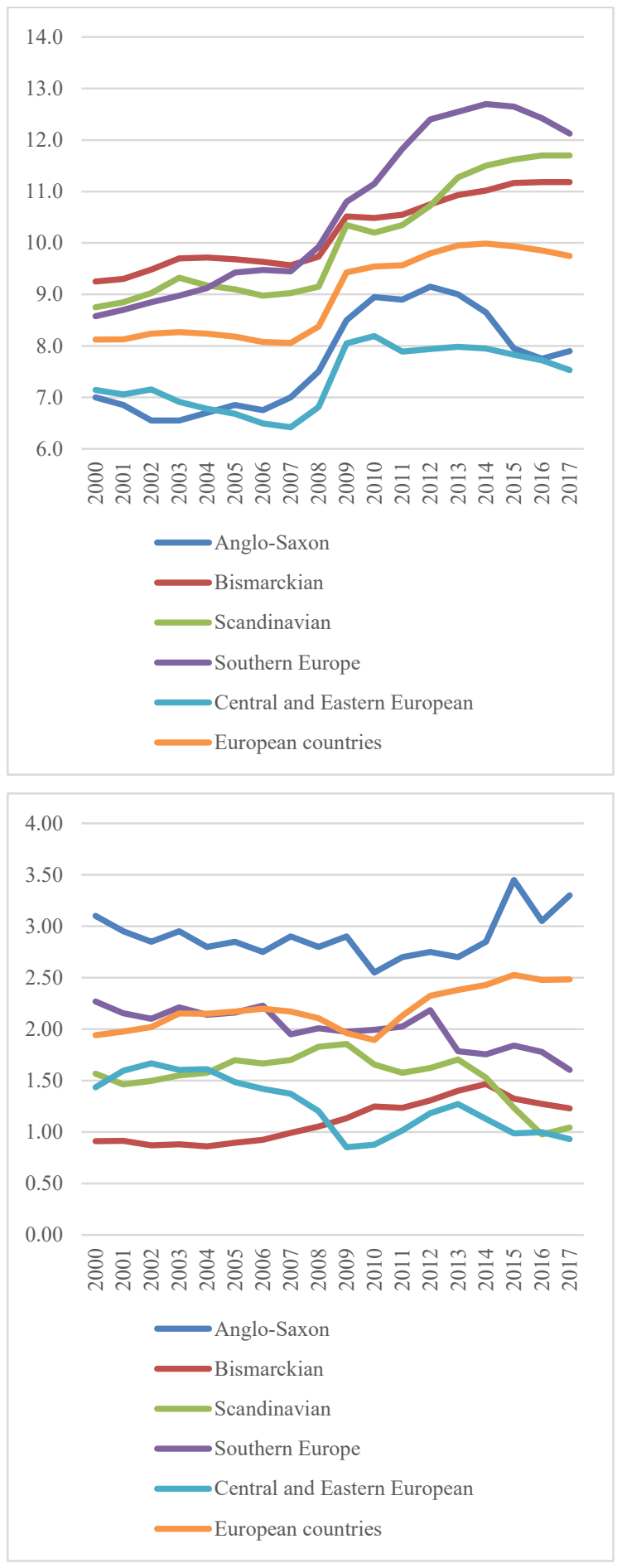

Figure 3. Old age-related expenditures by country groupings (top: averages in \% of GPD, bottom: standard deviations).

Source: Own compilation, data extracted from the Eurostat database

The amount of spending on family policy and children (not education) is a decisive element of welfare models.
Scandinavian countries are the most generous regarding family policy and providing benefits for children, these countries spent an average 3.1 percent of GDP on this issue in 2017. Not surprisingly, countries of Bismarckian model seize the second place by an average 2.22 percent of GDP. Anglo-Saxon, Southern European and Eastern European regimes spent on family policy and benefits for children below the average in 2017. It is worth highlighting that all welfare regimes have been spending more on this issue since 2000 measured by average values with exception of countries composing the Bismarckian model where the average spending was the same in 2017 compared to 2000. Despite the general increase in spending on public policies on families and children, the post-crisis period represents a declining trend in expenditures.

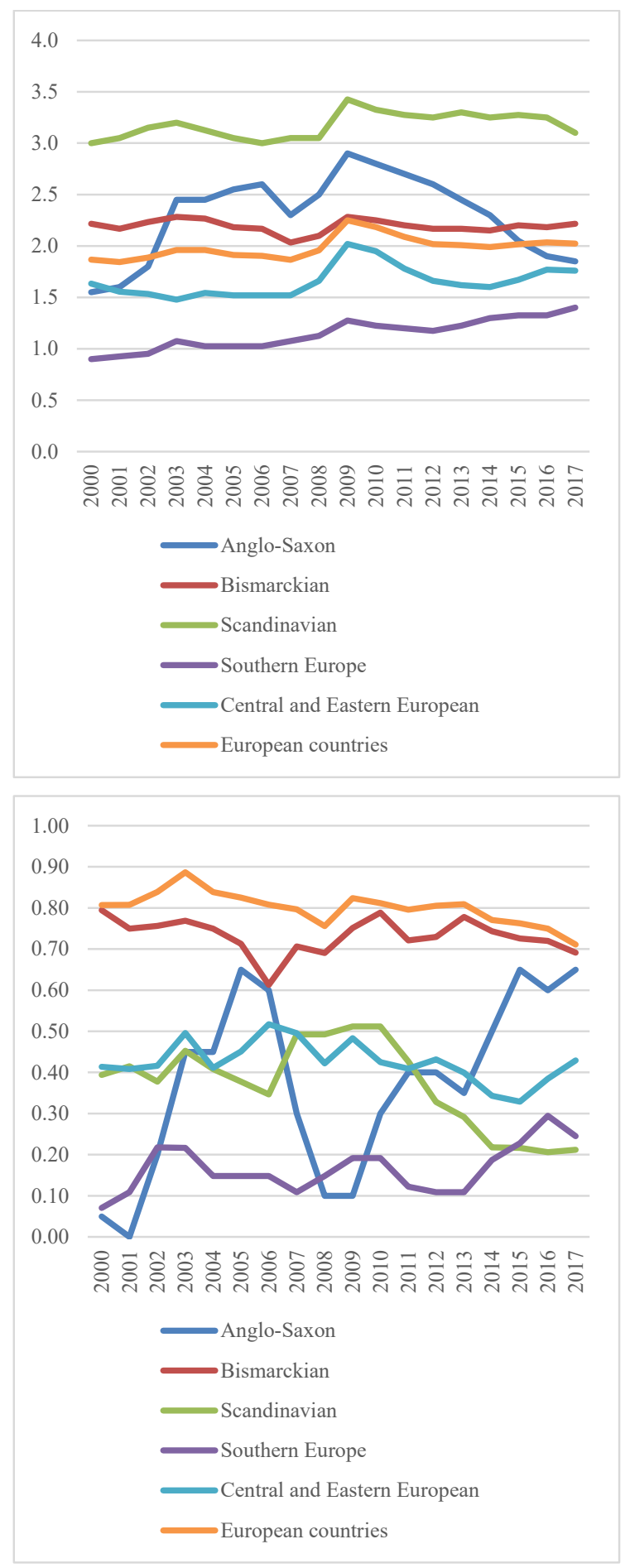


Figure 4. Spending on families and children in country groupings (top: averages in \% of GPD, bottom: standard deviations).

Source: Own compilation, data extracted from the Eurostat database

Regarding convergence spending on families and children, we can draw two findings. First, standard deviations in country groupings have been very low during the last two decades, consequently there is strong convergence inside clusters, and on the other hand there is relatively firm convergence among all 26 European countries. Second, standard deviation has been increasing in some country groupings (Anglo-Saxon, Southern European and CEE), thus the post-crisis period brought a very moderate divergence in within the regimes (see Figure 4.).

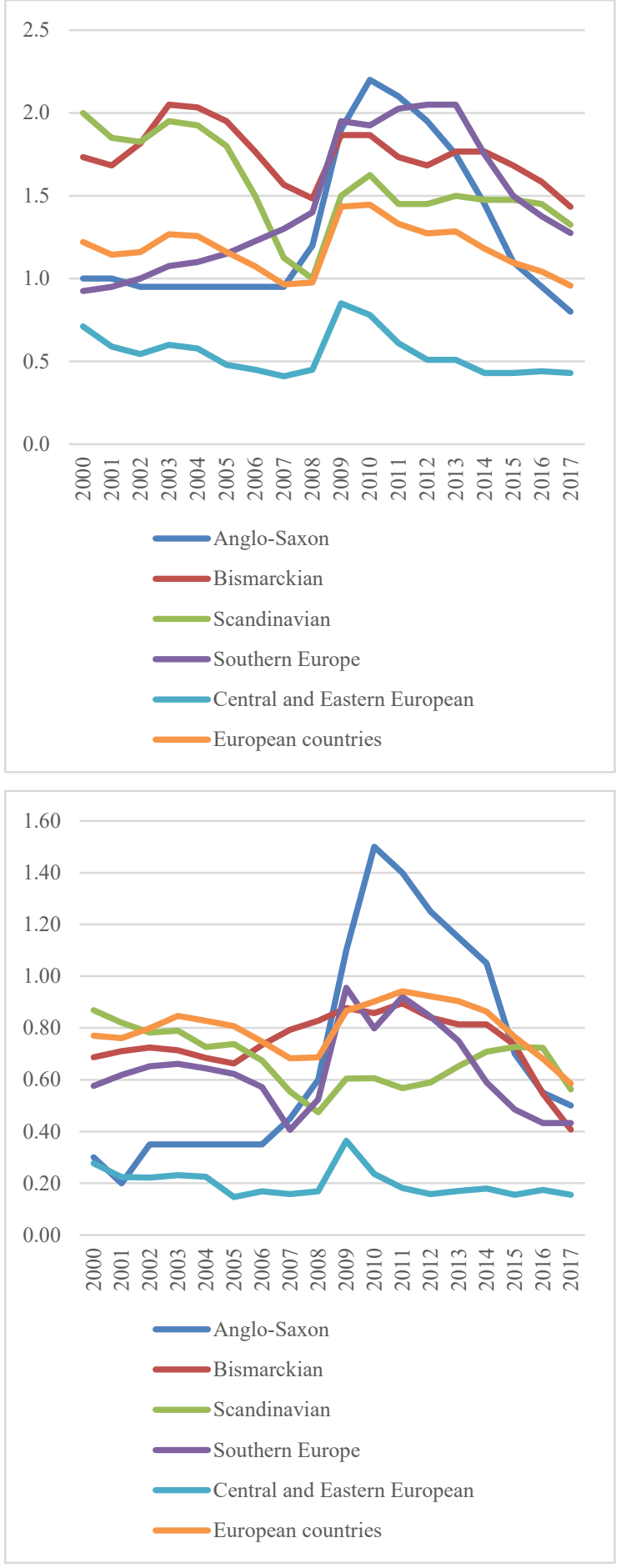

Figure 5. Unemployment-related spending in country groupings (top: averages in \% of GPD, bottom: standard deviations).

Source: Own compilation, data extracted from the Eurostat database

Rising or declining unemployment rate is one of the best indicators of economic processes. During the pre-crisis period, almost all European countries enjoyed the positive impacts of Great Moderation and economic prosperity. So, no wonder that unemployment rates were steadily decreasing, and employment rates were significantly rising in this period. The global financial crisis generated years of recession; thus, unemployment has been rapidly rising, which culminated in additional expenditures for European countries. The euro crisis manifested in prolonged and sustained high unemployment rates (an extremely high youth unemployment rates) in Southern European countries and Ireland. Furthermore, several other countries, including France and Belgium, have sufferer for sustained high unemployment rates. In contrast, many countries (for example Visegrad countries, Austria and Germany) have reached record low unemployment rates by the middle of the 2010 s.

Unemployment-related expenditures accurately reflect the above-mentioned trends. Unemployment-related spending is the lowest in the Central and Eastern European country groups, the average value was 0.43 in per GDP in 2017 and moreover, significantly decreased since both 2000 and the global financial crisis. In the case of the Scandinavian. the Anglo-Saxon and the Bismarckian models, expenditures have also been reduced but average values of country groupings were higher than in Central and Eastern European countries. And finally, Southern European countries have significantly reduced spending on unemployment-related issues since the global financial crisis, however, in 2017 it was still higher than in 2000.

Standard deviations of unemployment-related spending in country groupings have been exceptionally low during the last two decades. Apart from the Anglo-Saxon group, the standard deviation has been decreased between 2000 and 2007, so the groups have been turning to more homogenous (Figure 5.).

\section{CONCLUSIONS}

Welfare state models are in a constant change. The pre-crisis period can be characterized by economic prosperity and increasing well-being, while this period was followed by a decade-long disastrous series of events such as the global financial crisis, euro crisis, the Brexit, migration crisis, the harmful impacts of globalization (rising economic uncertainty and inequality), adverse demographic changes and emerging social risks. In this study, we have presented a comprehensive theoretical framework regarding welfare regimes and welfare state models. We have capitalized on descriptive statistics and a single convergence analysis based on standard deviation in order to capture alterations in national welfare models of 26 European countries and among acknowledged welfare regimes.

Our results, in general, suggest that convergence among welfare states (different indicator of social spending) of European countries is particularly weak, however convergence inside country groupings is significantly stronger apart from the AngloSaxon group. The pre-crisis period was characterized by a stronger convergence among European countries as a consequence of economic prosperity and intense EU intervention. However, EU bodies have overly concentrated on macroeconomic issues with the introduction of new (macro)economic governance and regulatory framework and 
limited national decision-makers to effectively offset emerging challenges with social policies.

The convergence and EU's intervention nexus needs more and detailed research to carry out. In order to gain more robust results, we plan to expand our scope and analyse a large number of indicators, thus we can create composite indexes to capture social model convergence among European countries.

\section{REFERENCES}

1. Goodin, R. E.; Headey, B.; Muffels, R.; Dirven, H.-J. (1999) The Real Worlds of Welfare Capitalism. Cambridge, UK: Cambridge University Press

2. Lange, P., Meadwell H. (1991) Typologies of Democratic Systems: Form Political Inputs to Political Economy. In Wiarda, H. J. (Ed.). New Directions in Comparative Politics. Boulder, CO: Westview, 82-117

3. Midgley, J. (1997) Social Welfare in Global Context. Thousand Oaks, London: Sage Publications.

4. Esping-Andersen, G. (1990) The three worlds of welfare capitalism. Princeton, NJ: Princeton University Press

5. Esping-Andersen, G. (1996) Occupational welfare in the social policy nexus. In Shalev, M. (Ed.). The privatization of social policy? New York: Macmillan Press, 327-338

6. Brooks, C.; Manza, J. (2006) Why do welfare states persist? The Journal of Politics, 68(4), 816-827.

7. Cornelisse, P. A.; Goudswaard K. P. (2002) On the convergence of social protection systems in the European Union. International Social Security Review, 55(3), 3-17.

8. Achterberg, P.; Yerkes M. (2009) One welfare state emerging? Convergence versus divergence in 16 western countries. Journal of Comparative Social Welfare, 25(3), 189-201.

9. Regent, S. (2003) The Open Method of Coordination: A New Supranational Form of Governance? European Law Journal, 9(2), 190-214

10. Büchs, M. (2009) The Open Method of Coordination Effectively preventing welfare state retrenchment? In: Kröger, Sandra (ed.): What have we learnt: Advances pitfalls and remaining questions in OMC research, European Integration online Papers (EIoP), Special Issue $1,13(11)$.

11. Ferrera, M. (1996) The "Southern" Model of Welfare State in Social Europe. Journal of European Social Policy, 6(1), 17-37.

12. Kuitto, K.; Jahn, D.; Düpont; N. (2012) Welfare Policy Institutions in the Enlarged European Union: Convergence, Divergence or Persistence? Greifswald Comparative Politics, Working Paper, No. 2012-01. Greifswald: University of Greifswald.

13. Kertész, K. (2012) Hogyan mérjük a pártok centralizáltságának fokát? (How can we measure support of parties?); Tudományos Közlemények, ÁVF, 28, september, 95-110.

14. Kertész, K. A magyar pártok belső szervezeti felépítésének összehasonlítása. (Comparison of Hungarian inner party structures), Társadalomtudományi gondolatok a harmadik évezred elején (editor: Karlovitz János Tibor), 184-198. Publisher: International Research Institute s.r.o, Komarno, Slovakia. 